\title{
A STUDY OF SOME OF THE PHYSIOLOGICAL EFFECTS OF SULFANILAMIDE. I. CHANGES IN THE ACID BASE BALANCE
}

\author{
By ALEXIS F. HARTMANN, ANNE M. PERLEY AND HENRY L. BARNETT \\ (From the Department of Pediatrics, Washington University School of Medicine, and the St. \\ Louis Children's Hospital, St. Louis)
}

(Received for publication February 21, 1938)

Southworth (1), in February 1937, reported two cases of "clinical acidosis" as a result of administration of prontylin in large doses and fifteen consecutive cases treated with the drug who showed a consistent, though variable, drop in the carbon dioxide combining power of the blood. Recently, Brown and Bannick (2) stated that they had noted a decline in the carbon dioxide combining power of the blood of patients treated with sulfanilamide and that actual acidosis at times occurred. They point out that the use of ten grains of sodium bicarbonate with each dose of the drug, as suggested by Long and Bliss, might be of value both in preventing acidosis, and also, as suggested by Helmholz and Osterberg (3), in increasing the bactericidal activity of the drug in the treatment of infections of the urinary tract.

In an earlier paper (4) from this laboratory, it was reported that the administration of moderately large doses of sulfanilamide commonly caused hyperventilation which simulated the dyspnea of acidosis. Suspicion concerning the significance of such overbreathing was aroused when it was noted that such hyperventilation seemed out of proportion to the rather moderate average reduction of 15 to 20 volumes per cent carbon dioxide content of the blood which occurred quite regularly in subjects in whom there could be found none of the more common causes for the development of acidosis. We then demonstrated that, coincident with the fall of the carbon dioxide content of serum, the $\mathrm{pH}$ of the urine was quite regularly above 7 , which observation led us to conclude that the change in the acid base equilibrium was actually a carbon dioxide deficit type of alkalosis, secondary to primary hyperventilation, and not acidosis. At this time we wish to report more detailed data regarding the changes in the acid base equilibrium which seem to substantiate our conclusions but which differ from those which have recently been obtained by Marshall (5) in dogs.

Following sulfanilamide administration, we followed closely changes in $\mathrm{pH}$ and bicarbonate content of the urine, and at somewhat longer intervals determined the $\mathrm{pH}$ and carbon dioxide content of the blood serum, as well as the blood sulfanilamide and methemoglobin concentrations. in two normal adult subjects and in two children. ${ }^{\circ}$ Preliminary observations of $\mathrm{pH}$ and carbon dioxide content of the urine prior to sulfanilamide administration were made on the two normal subjects and one of the hospital patients. In most of the experiments, $0.2 \mathrm{gram}$ of sulfanilamide per kilogram of body weight was given in a period of two hours. In the case of the hospital patients, the drug administration was continued with the doses as indicated in the tables. Tables I and II give the chemical findings on the normal adult subjects and Tables III and IV on the hospital patients.

\section{DISCUSSION}

From a study of the tables, it will be seen that the specimens of urine just preceding sulfanilamide administration were invariably acid with low carbon dioxide content, but always became alkaline with a marked rise in carbon dioxide content within two hours after the drug administration was started. Accompanying this increased excre-

\footnotetext{
1 The urine was collected under oil and its $\mathrm{pH}$ determined by use of the glass electrode without protection against loss of carbon dioxide during the determinations. Blood was collected under oil and serum $\mathrm{pH}$ was determined by the method of Hastings and Sendroy (6) ; carbon dioxide content of the urine and serum by use of the manometric Van Slyke apparatus (7). Blood sulfanilamide was determined by the method of Marshall (8), and methemoglobin by the method of Wendel (unpublished). Determinations of blood lactic acid were made in several instances, for which the method of Friedmann, Cotonio, and Shaffer, as modified by Wendel (9), was used.
} 
TABLE I

Subject 1. Normal male, age 23 years, weight 73 kilograms

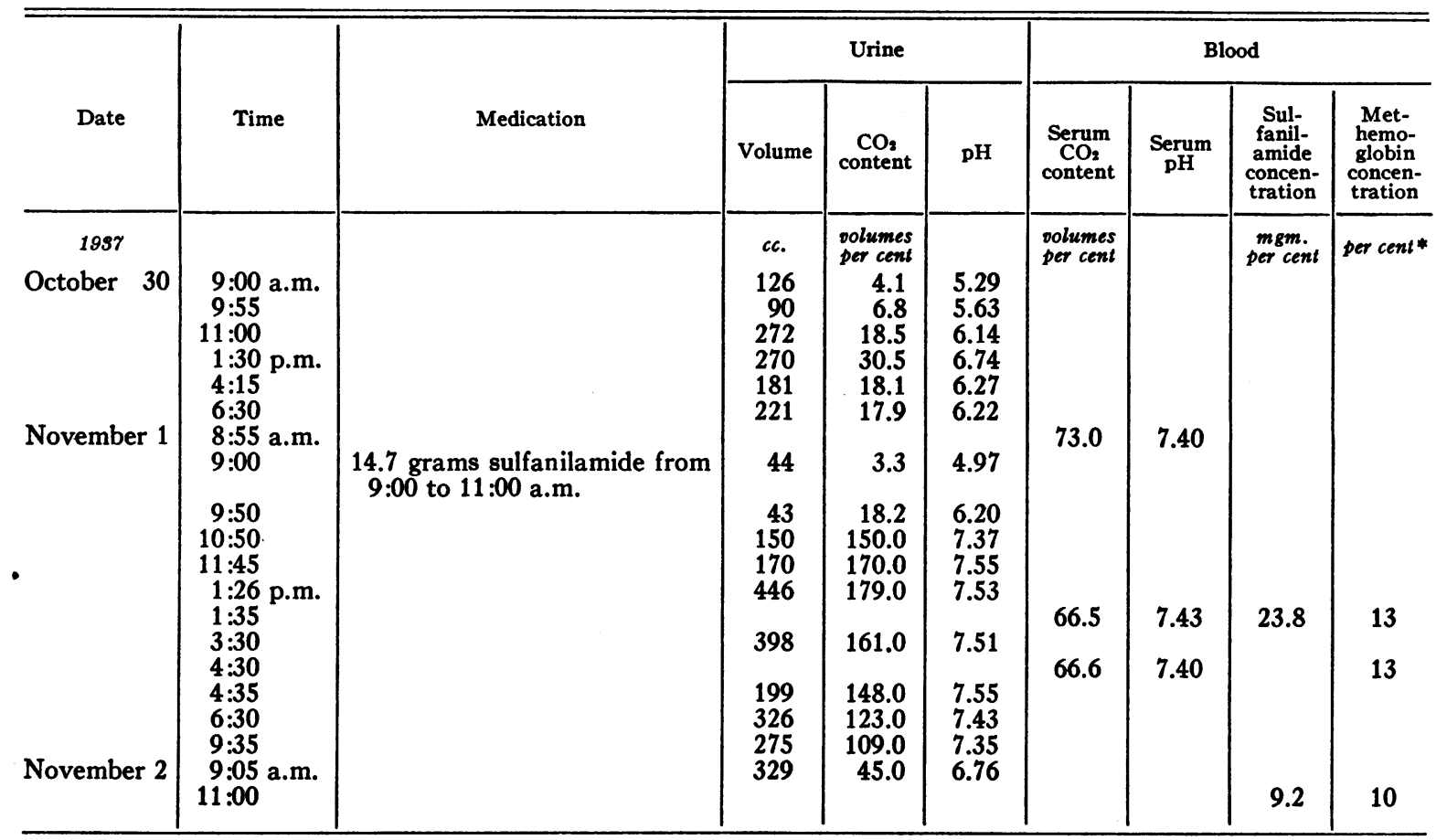

* Methemoglobin concentration expressed as per cent of total hemoglobin pigment.

tion of bicarbonate, there was a fall in the serum carbon dioxide content which ranged from 5.5 to 24.7 volumes per cent. During this period, we observed in every case a slight rise in the serum $\mathrm{pH}$.

The production of alkaline urine with simultaneous reduction of the carbon dioxide content of the blood serum and rise in serum $\mathrm{pH}$ has been described by a number of investigators (10, $11,12)$ as the result of voluntary hyperventilation. The accepted explanation for these changes is as follows. The hyperventilation lowers the carbon dioxide tension of the alveolar air and consequently that of the plasma. The immediate result of the decreased plasma carbon dioxide tension is an increase in the ratio of $\frac{\mathrm{BHCO}_{3}}{\mathrm{H}_{2} \mathrm{CO}_{3}}$ with an increase in the plasma $\mathrm{pH}$. One manifest compensatory response to this alteration is the increased excretion of bicarbonate by the kidney in an effort to reestablish the normal ratio between bicarbonate and carbonic acid, upon which the $\mathrm{pH}$ of the plasma depends. The reduction of base bicarbonate in the serum probably should not be attributed wholly to the excretion of bicarbonate by the kidney. At an elevated $\mathrm{pH}$ of the blood serum, other blood buffers, particularly phosphates and proteinates, claim more base, which is yielded by bicarbonate. In addition, chloride shift from the red blood cell to the plasma would tend further to reduce bicarbonate, as would also the slight and transient ketosis which seems frequently to be associated with the alkalosis of hyperventilation (13), and which we have also noted following sulfanilamide administration. Aside from such mild ketosis, however, there seems to be no other acid accumulation; certainly there is no significant rise in lactic acid, which conceivably might occur as a result of anoxemia secondary to methemoglobin formation. Accumulation of phosphate has been shown not to occur and elevation of serum sulphate seems very unlikely. Even if abnormal acid accumulation were to occur and explain the reduction in serum bicarbonate, we would still have to explain the rising $\mathrm{pH}$ of the serum.

Our findings in regard to the direction of the 
TABLE II

Subject 2. Normal female, age 33 years; weight 47 kilograms

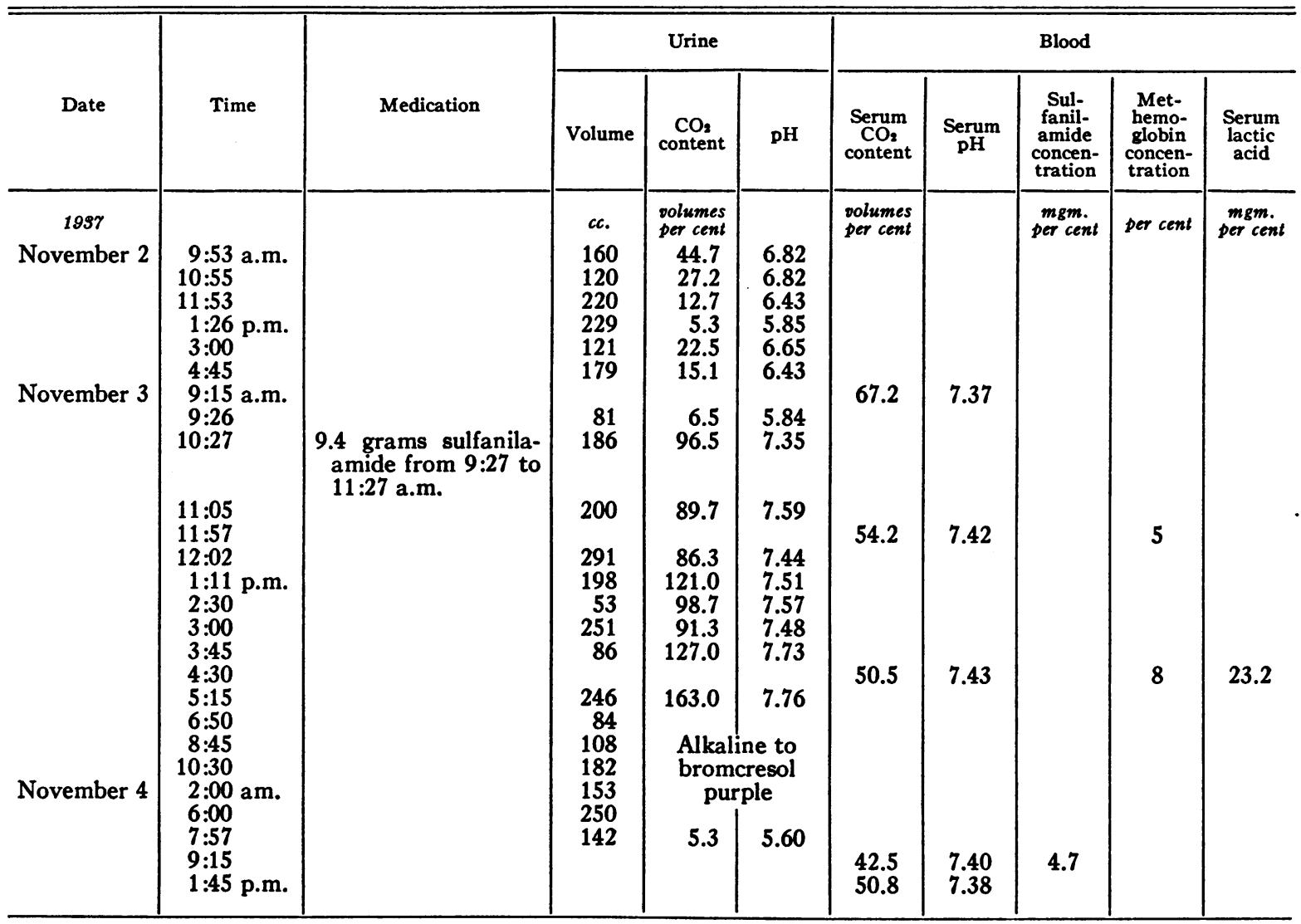

$\mathrm{pH}$ change of the blood serum are in apparent disagreement with those reported by Marshall et al. (5) in dogs. It can be seen from our data that the $\mathrm{pH}$ values for the blood serum increased in every experiment. Although the changes were not very marked in some of the experiments, they become more significant when we consider that if the decrease in the carbon dioxide content of the blood serum were to be explained on the basis of acidosis, one would expect a definite fall in the $\mathrm{pH}$ value of the serum of about 0.10 (14). In the six experiments on three dogs reported by Marshall, the first actually showed a rise in serum $\mathrm{pH}$ of 0.06 during the period in which the carbon dioxide content of the serum fell 17.5 volumes per cent. In the second, and the only one in which an abnormally low $\mathrm{pH}$ was obtained, the carbon dioxide content of the serum actually rose during the period in which the $\mathrm{pH}$ of the serum was shown to fall. In the third, the variation in the $\mathrm{pH}$ of the serum during the control period was as great as the interpreted fall during the test period, and the $\mathrm{pH}$ of the serum at the end of the experiment was the same as at the beginning. In the other three experiments, a fall in the $\mathrm{pH}$ of the serum was obtained simultaneously with the reduction in the carbon dioxide content of the serum, but in only two of these was the fall commensurate with that expected from the degree of reduction of the carbon dioxide content of the serum (14). Whether, as Marshall suggests, some of his apparently discrepant results are owing to respiratory disturbances because of difficulty in controlling the experimental animals, and whether the difference between his findings and ours depends upon the larger doses of sulfanilamide which he used, cannot be stated, but it seems justifiable to conclude from our data obtained on human subjects that the change in the acid base balance is that of a carbon dioxide deficit type of 
TABLE III

Patient 1. Female, age 14 years, weight 55 kilograms. (Subacute bacterial endocarditis)

\begin{tabular}{|c|c|c|c|c|c|c|c|c|c|c|}
\hline \multirow[b]{2}{*}{ Date } & \multirow[b]{2}{*}{ Time } & \multirow[b]{2}{*}{ Medication } & \multicolumn{3}{|c|}{ Urine } & \multicolumn{5}{|c|}{ Blood } \\
\hline & & & Volume & $\underset{\text { content }}{\mathrm{CO}_{2}}$ & pH & $\begin{array}{c}\text { Serum } \\
\mathrm{CO}_{2} \\
\text { content }\end{array}$ & $\underset{\mathrm{pH}}{\text { Serum }}$. & $\begin{array}{l}\text { Sul- } \\
\text { fanil- } \\
\text { amide } \\
\text { concen- } \\
\text { tration }\end{array}$ & $\begin{array}{l}\text { Met- } \\
\text { hemo- } \\
\text { globin } \\
\text { concen- } \\
\text { tration }\end{array}$ & $\begin{array}{c}\text { Serum } \\
\text { lactic } \\
\text { acid }\end{array}$ \\
\hline $\begin{array}{c}1987 \\
\text { October } 23 \\
\text { October } 24 \\
\text { October } 25\end{array}$ & $\begin{array}{c}\text { 11:00 a.m. } \\
\text { 7:30 p.m. } \\
\text { 2:00 pm. } \\
\text { 9:20 a.m. } \\
\\
\text { 9:30 } \\
\text { 12:00 m. } \\
1: 25 \text { p.m. } \\
2: 15 \\
4: 00 \\
\\
7: 15 \\
8: 00 \\
10: 00 \\
3: 50 \text { a.m. } \\
9: 00 \\
9: 05 \\
12: 35 \text { p.m. } \\
3: 40 \\
5: 10 \\
8: 15 \\
7: 50 \text { am. } \\
8: 00\end{array}$ & $\begin{array}{l}11.0 \text { grams sulfanila- } \\
\text { mide from } 8: 45 \text { a.m. } \\
\text { to } 12: 00 \mathrm{~m} \text {. } \\
11.0 \text { grams of sul- } \\
\text { fanilamide per } 24 \\
\text { hours in } 6 \text { doses }\end{array}$ & $\begin{array}{r}242 \\
122 \\
\\
268 \\
\\
132 \\
\\
122 \\
116 \\
\\
139 \\
134 \\
126 \\
46 \\
100 \\
296\end{array}$ & $\begin{array}{r}\text { volumes } \\
\text { per cent } \\
3.9 \\
6.2 \\
5.7 \\
3.4 \\
\\
\\
161.0 \\
104.0 \\
\\
197.0 \\
\\
207.0 \\
\\
168.0 \\
13.8 \\
\\
18.8 \\
49.8 \\
73.0 \\
36.3 \\
39.6 \\
5.2\end{array}$ & $\begin{array}{l}7.69 \\
7.60 \\
7.79 \\
\\
7.87 \\
7.69 \\
6.13 \\
\\
6.42 \\
6.99 \\
7.12 \\
6.89 \\
6.74 \\
5.08\end{array}$ & $\begin{array}{l}67.3 \\
61.0\end{array}$ & $\begin{array}{l}7.37 \\
7.42\end{array}$ & $\begin{array}{l}17.6 \\
17.9\end{array}$ & $\begin{array}{l}10 \\
11\end{array}$ & $\underset{\text { per cent }}{\operatorname{mg} \text { cent }}$ \\
\hline
\end{tabular}

alkalosis rather than that of an alkali deficit type of acidosis.

Disregarding the discrepancies in serum $\mathrm{pH}$ data, our conclusions still seem logical. The only other explanation for a fall of serum carbon dioxide content with a simultaneous increase in urinary $\mathrm{pH}$ to values above 7 is, as Marshall suggests, a failure of the tubules to reabsorb bicarbonate, and there is considerable evidence against this supposition. In several of our experiments the urines were tested for dextrose, and none of them produced any reduction of Benedict's qualitative reagent, so that dextrose, at least, was reabsorbed normally. Aside from alkalosis, the only commonly known cause for failure of reabsorption of bicarbonate by tubular epithelium is the very rapid passage of urine through the tubules leading to polyuria, which was true neither in Marshall's experiments nor to an extensive degree in our own. Marshall, on the contrary, has shown that the rate of glomerular filtration is decreased and that there is no pathological or laboratory evidence of kidney damage with the doses of sulfanilamide employed. Besides these indirect evidences against the possibility of failure of the tubules to reabsorb bicarbonate, an experiment to be described later in this paper offers direct evidence that such is not the case. The data for this experiment are given in Table V. Ammonium chloride was given preliminary to the administration of sulfanilamide, and the urine became practically free of bicarbonate. It can be seen from Table $\mathrm{V}$ that the $\mathrm{pH}$ of the urine remained as low for five hours after the sulfanilamide was given as it was during the two hours prior to its administration. If there were to have been failure of the tubules to reabsorb bicarbonate due to the sulfanilamide, there is no reason to suppose that ammonium chloride would have prevented this effect. We believe, therefore, that the fall of serum carbon dioxide content following sulfanilamide administration may in most instances be explained primarily on the basis of carbon dioxide deficit resulting from hyperventilation.

In some cases, hyperventilation may not be 
TABLE IV

Patient 2. Female, age 9 years, weight 20 kilograms. (Pyelitis)

\begin{tabular}{|c|c|c|c|c|c|c|c|c|c|}
\hline \multirow[b]{2}{*}{ Date } & \multirow[b]{2}{*}{ Time } & \multirow[b]{2}{*}{ Medication } & \multicolumn{3}{|c|}{ Urine } & \multicolumn{4}{|c|}{ Blood } \\
\hline & & & Volume & $\begin{array}{c}\mathrm{CO}_{2} \\
\text { content }\end{array}$ & $\mathrm{pH}$ & $\begin{array}{c}\text { Serum } \\
\mathrm{CO}_{2} \\
\text { content }\end{array}$ & $\underset{\mathbf{p H}}{\text { Serum }}$ & $\begin{array}{l}\text { Sul- } \\
\text { fanil } \\
\text { amide } \\
\text { concen- } \\
\text { tration }\end{array}$ & $\begin{array}{l}\text { Met- } \\
\text { hemo- } \\
\text { globin } \\
\text { concen- } \\
\text { tration }\end{array}$ \\
\hline $\begin{array}{l}\text { November } 6 \\
\text { November } 7\end{array}$ & $\begin{array}{c}\text { 5:45 p.m. } \\
6: 10 \text { a.m. } \\
8: 45 \\
9: 20 \\
9: 20 \\
10: 35 \\
11: 10 \\
11: 30 \\
11: 40 \\
1: 55 \text { p.m. } \\
3: 35 \\
3: 40 \\
4: 00 \\
7: 00 \\
8: 10 \\
8: 15 \\
9: 50 \\
11: 00 \\
8: 00 \text { a.m. } \\
11: 00 \\
12: 10 \text { pm. } \\
1: 45 \\
2: 00 \\
3: 05 \\
3: 55 \\
4: 30 \\
10: 00 \text { a.m. } \\
10: 25 \\
12: 45 \text { p.m. }\end{array}$ & $\begin{array}{l}\text { Methylene blue } 2 \text { cc. } 1 \text { per cent } \\
\text { solution intravenously } \\
4.0 \text { grams, sulfanilamide from } \\
9: 00 \text { to } 11: 00 \text { a.m. } \\
\text { Methylene blue } 1 \text { cc. } 1 \text { per cent } \\
\text { solution, intravenously } \\
4.0 \text { grams of sulfanilamide per } \\
24 \text { hours in } 6 \text { doses } \\
\text { Sulfanilamide stopped } \\
\text { Sulfanilamide started } 2.0 \text { grams } \\
\text { per } 24 \text { hours }\end{array}$ & $\begin{array}{r}c c . \\
216 \\
91 \\
\\
51 \\
159 \\
90 \\
\\
161 \\
126 \\
141 \\
\\
98 \\
60 \\
90\end{array}$ & $\begin{array}{r}\text { volumes } \\
\text { per cent } \\
24.5 \\
4.7 \\
\\
4.9 \\
62.7 \\
39.8 \\
\\
63.6 \\
127.0 \\
141.0 \\
\\
149.0 \\
112.0\end{array}$ & $\begin{array}{l}6.20 \\
5.41 \\
\\
5.65 \\
7.33 \\
7.27 \\
\\
7.53 \\
7.70 \\
7.75 \\
\\
7.75 \\
7.65 \\
7.20\end{array}$ & $\begin{array}{c}\begin{array}{c}\text { volumes } \\
\text { per cent }\end{array} \\
58.7\end{array}$ & $\begin{array}{l}7.43 \\
7.45\end{array}$ & $\underset{\text { per cent }}{m g m .}$ & $\begin{array}{l}\text { Less } \\
\text { than } 3 \\
\text { Less } \\
\text { than } 3\end{array}$ \\
\hline
\end{tabular}

particularly noticeable, but in certain of our subjects it was quite marked. Two patients, one child and one adult, on whom we do not have preliminary data, showed very marked increase both in depth and rate of breathing after having received both large and continued doses of sulfanilamide. At the time when the hyperventilation was extreme, the serum $\mathrm{pH}$ values were found to have reached 7.55 and 7.57, respectively. In the child, signs of tetany were present. The effectiveness of the hyperventilation in producing carbon dioxide deficit depends more upon increase in depth of respiration than increased rate, and therefore overbreathing may be easily overlooked until it becomes quite marked.

In endeavoring to explain the hyperventilation, we wished particularly to determine whether the sudden reduction in the oxygen carrying capacity of the blood resulting from the rapid accumulation of methemoglobin might be largely responsible. We therefore prevented the accumulation of any appreciable amount of methemoglobin in Patient 2 by the injection of methylene blue (7). Despite the fact that the methemoglobinemia was extremely slight, the patient obviously hyperventilated, and the usual chemical changes ensued. Furthermore, there appeared to be no correlation in other cases between the degree of methemoglobin accumulation and the extent of hyperventilation.

Symptoms which developed following these large doses of sulfanilamide varied considerably 
in different individuals, but those most consistently noted were as follows. Within thirty minutes after the first dose had been taken, vertigo was experienced, and within two hours, hyperventilation, nausea, anorexia, increased thirst, and cyanosis were also noted. These symptoms continued and were accompanied by drowsiness, irritability, and very evident mental confusion involving principally false perception of intervals of time, extreme difficulty in concentration, and slow response to simple questions. Usually there was no gross disorientation. Recovery from the subjective symptoms, in the normal subjects, was not complete for forty-eight hours, with vertigo, anorexia, and drowsiness persisting throughout the day following drug administration. It is interesting to note the similarity of many of these symptoms to those described by Collip and Backus (10) and Lepper and Martland (12) in subjects who voluntarily overbreathed and became alkalotic. Dizziness, drowsiness, and increased thirst were characteristic, as well as irritability, unreasonableness, and a lowering of the critical faculty.

To test to what extent the subjective symptoms which we observed following the administration

TABLE V

Subject 2. Normal female, age 33 years, weight 47 kilograms

\begin{tabular}{|c|c|c|c|c|c|c|c|c|c|c|c|}
\hline \multirow[b]{2}{*}{ Date } & \multirow[b]{2}{*}{ Time } & \multirow[b]{2}{*}{ Medication } & \multicolumn{3}{|c|}{ Urine } & \multicolumn{5}{|c|}{ Blood } & \multirow{2}{*}{$\begin{array}{c}\text { Scott } \\
\text { Wilson } \\
\text { expired } \\
\text { air* }\end{array}$} \\
\hline & & & Volume & $\mathrm{pH}$ & $\begin{array}{l}\text { Ferric } \\
\text { chlo- } \\
\text { ride* }\end{array}$ & $\begin{array}{c}\text { Serum } \\
\mathrm{CO}_{2} \\
\text { content }\end{array}$ & $\underset{\text { pH }}{\text { Serum }}$ & $\begin{array}{c}\text { Serum } \\
\text { inor- } \\
\text { ganic } \\
\text { phos- } \\
\text { phorus }\end{array}$ & $\begin{array}{c}\text { Serum } \\
\text { lactic } \\
\text { acid }\end{array}$ & $\begin{array}{c}\text { Sul- } \\
\text { fanil- } \\
\text { amide } \\
\text { concen- } \\
\text { tration }\end{array}$ & \\
\hline $\begin{array}{c}19 s 7 \\
\text { December } 26 \\
\text { December } 27\end{array}$ & $\begin{array}{c}11: 15 \text { p.m. } \\
12: 05 \text { a.m. } \\
3: 00 \\
6: 00 \\
7: 05-8: 00 \\
8: 30-9: 37 \\
10: 14 \\
10: 15 \\
\\
10: 23 \\
11: 13 \\
11: 15 \\
11: 45 \\
12: 15 \text { p.m. } \\
1: 03 \\
1: 15 \\
1: 30 \\
3: 00 \\
4: 15 \\
4: 50 \\
7: 18 \\
7: 20 \\
\\
8: 50 \text { a.m. }\end{array}$ & $\begin{array}{l}\text { Ammonium chloride } 2 \text { grams } \\
\text { Ammonium chloride } 2 \text { grams } \\
\text { Ammonium chloride } 2 \text { grams } \\
\text { Ammonium chloride } 3 \text { grams } \\
9.7 \text { grams sulfanilamide } \\
\text { from } 10: 15 \text { a.m. to } 12: 15 \text { p.m. } \\
\text { Ammonium chloride } 3 \text { grams }\end{array}$ & $\begin{array}{r}92 \\
248 \\
\\
238 \\
275 \\
217 \\
350 \\
163 \\
216 \\
\\
56\end{array}$ & $\begin{array}{c}4.48 \\
4.57 \\
\\
4.44 \\
4.45 \\
4.57 \\
4.47 \\
4.82 \\
4.85 \\
\text { Aci } \\
\text { meth } \\
5.02\end{array}$ & $\begin{array}{c}0 \\
+ \\
+ \\
+ \\
+ \\
+ \\
+ \\
+ \\
\text { d to } \\
\text { yl red } \\
+\end{array}$ & $\begin{array}{l}50.5 \\
\\
37.3 \\
35.0 \\
37.6\end{array}$ & $\begin{array}{l}7.42 \\
\cdot \\
7.35\end{array}$ & \begin{tabular}{|}
$\underset{\text { per cent }}{\operatorname{mgm}}$ \\
3.8
\end{tabular} & $\underset{\text { per cent }}{\operatorname{mgm} .}$ & $\underset{\text { per cent }}{\operatorname{mgm} .}$ & + \\
\hline
\end{tabular}

* It will be noted from the data in Table $\mathrm{V}$ that within an hour after the first dose of sulfanilamide, the urine gave a slightly positive test with ferric chloride and the reaction became strongly positive within four hours, and remained so for two days. The color which developed with ferric chloride was not the typical Bordeaux red customarily seen with clinical ketosis, but was more purple and very intense. The Rothera test also was positive. Coincident with the positive ferric chloride tests in the urines, positive Scott-Wilson tests were obtained when the subject blew through this reagent. When the serum filtrates were distilled into Scott-Wilson reagent preliminary to lactic acid determinations, positive tests also resulted. Quantitative estimations of acetone bodies were not made at the time of the experiment, but some days later one of the specimens of urine which still showed strongly positive ferric chloride and Rothera tests, when refluxed with Van Slyke's mercuric sulfate reagent (15), gave insignificant amounts of precipitate. Further investigations of these findings are to be made in an effort to determine the significance and the extent of the ketosis which is suggested by the positive qualitative tests, and to determine the rôle that ammonium chloride may have had in producing these reactions, which persisted for an unusually long period. 
of the drug are related to alkalosis and to what degree tolerance may be acquired by repeated administration, the following experiments were made. Over a period of twelve hours, one of the normal adults, Subject 2, was given the amount of ammonium chloride calculated to lower the carbon dioxide content of the body fluid 15 volumes per cent, and, at the end of this period, was again given 0.2 gram of sulfanilamide per kilogram in two hours. All of the former determinations were repeated, the results of which are given in Table V. From this data it can be seen that the development of alkalosis was prevented; the $\mathrm{pH}$ of the urine remained consistently below 5 for twenty-three hours, and the $\mathrm{pH}$ of the blood serum fell from 7.42 to 7.30. Particular attention was given to comparing the subjective symptoms experienced during this experiment with those which developed during the former one on this subject. In general, all the previously described symptoms were less marked except the hyperventilation which subjectively seemed more severe. However, when the sulfanilamide experiment on Subject 1 was repeated, the results of which are given in Table VI, and in which the alkalosis was again allowed to develop, comparable diminution in the symptoms likewise was noted.
We feel, although the drug was not taken a third time by Subject 2, that the decreased intensity of the symptoms may be explained possibly on the basis of an acquired tolerance to the drug rather than to prevention of alkalosis.

Even if it is later definitely found that alkalosis may not play an important rôle in the production of disagreeable symptoms, routine alkali administration in conjunction with sulfanilamide as recommended by Long and Bliss and adopted by others seems to us not only not indicated but definitely undesirable under certain circumstances. It is true that amounts of alkali as recommended (10 grains of sodium bicarbonate with each dose of sulfanilamide) and even much more in the form of sodium lactate may at times be rapidly excreted into the urine without interfering with compensation for carbon dioxide deficit (4). When, however, a deficiency of total fixed base in the body fluids is present (such as occurs for instance when marked vomiting with loss of acid gastric juice is associated with acute infections of the urinary tract), the physiological renal response is restriction of base excretion into the urine and the consequent formation of acid urine (low in bicarbonate). In such cases another type of alkalosis is often present-due to excess of

TABLE VI

Subject 1. Normal male, age 23 years, weight 73 kilograms

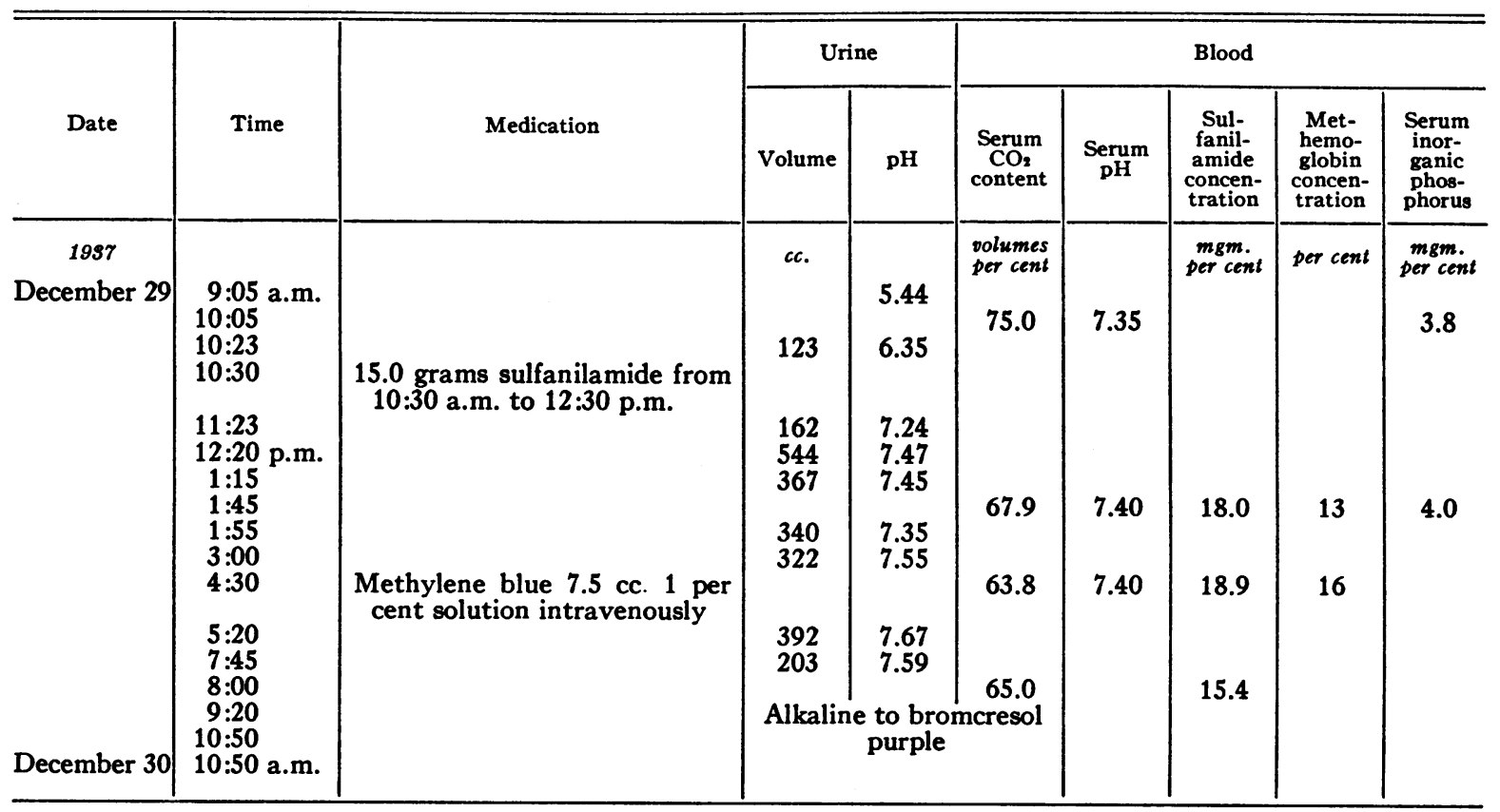


bicarbonate in the blood, compensation for which is depressed respiration and not excretion of alkali into the urine. Further alkali administration could only increase the degree of alkalosis, and add to its danger.

It should be noted from the tables, however, that the reaction of the urine may swing back to the acid zone, even though sulfanilamide administration is continued. The implications of the explanation of this are of interest. When the reduction of the base bicarbonate in the serum has reached the level at which, despite the decrease in carbonic acid brought about by hyperventilation, the ratio of bicarbonate: carbonic acid has again reached the normal value of $20: 1$, then there is no further need to excrete bicarbonate into the urine, and the latter may again become normally acid. At this time, the $\mathrm{pH}$ of the blood should be lower than it was when bicarbonate was being excreted in excessive amounts, and the data confirm this expectation. The carbon dioxide content of the serum at this same time would still be reduced because both bicarbonate and carbonic acid are below normal levels. It is easily conceivable that, with this existing bicarbonate deficit, a true acidosis might readily develop should ketosis, lactic, or other acid accumulation occur, or, on the other hand, should the hyperventilation suddenly cease, allowing carbonic acid to accumulate. This also has a bearing on the treatment of urinary tract infections. If it is desired to keep the urine alkaline in such subjects, this could be accomplished more safely by administration of sodium lactate from which alkali becomes available gradually. It should be remembered, however, that chloride, if deficient, may also have to be administered in order for alkali to be excreted into the urine, and for alkalosis of the base bicarbonate excess type to be avoided (16). Simultaneous administration of both substances may be accomplished very satisfactorily by using mixtures of molar sodium $r$-lactate and Ringer's solution. When mixed in equal parts, one to two cc. per kilogram given every four hours should maintain alkalinity of the urine with safety, provided extreme degrees of renal insufficiency are not present. The substitution of sodium lactate for sodium bicarbonate also has the advantage of preventing undesirable reduction of gastric acidity.

\section{BIBLIOGRAPHY}

1. Southworth, H., Acidosis associated with the administration of para-amino-benzene-sulfonamide (prontylin). Proc. Soc. Exper. Biol. and Med., 1937, 36, 58.

2. Brown, A. E., and Bannick, E. G., The use of sulfanilamide and prontosil solution. Proc. Staff Meet., Mayo Clin., 1937, 12, 644.

3. Helmholz, H. F., and Osterberg, A. E., Rate of excretion and bactericidal power of sulfanilamide (prontylin) in the urine. Proc. Staff Meet., Mayo Clin., 1937, 12, 377.

4. Basman, J., and Perley, A. M., Report of patients treated with sulfanilamide at the St. Louis Children's Hospital. J. Pediat., 1937, 11, 212.

5. Marshall, E. K., Jr., Cutting, W. C., and Emerson, K., Jr., The toxicity of sulfanilamide. J. A. M. A., 1938, 110, 252.

6. Hastings, A. B., and Sendroy, J., Studies of acidosis. $\mathrm{XX}$. The colorimetric determination of blood $\mathrm{pH}$ at body temperature without buffer standards. J. Biol. Chem., 1924, 61, 695.

7. Van Slyke, D. D., and Neill, J. M., The determination of gases in blood and other solutions by vacuum extraction and manometric measurements. J. Biol. Chem., 1924, 61, 523.

8. Marshall, E. K., Jr., Determination of sulfanilamide in blood and urine. Proc. Soc. Exper. Biol. and Med., 1937, 36, 422.

9. Wendel, W. B., A note on the determination of lactic and pyruvic acids. J. Biol. Chem., 1933, 102, 47.

10. Collip, J. B., and Backus, P. L., The effect of prolonged hyperpnoea on the carbon dioxide combining power of the plasma, the carbon dioxide tension of the alveolar air and the excretion of acid and basic phosphate and ammonia by the kidney. Am. J. Physiol., 1920, 51, 568.

11. Grant, S. B., and Goldman, A., A study of forced respiration: Experimental production of tetany. Am. J. Physiol., 1920, 52, 209.

12. Lepper, E. H., and Martland, M., Variations in the $\mathrm{pH}$ and bicarbonate of the plasma and the alveolar $\mathrm{CO}_{2}$ during forced breathing. Biochem. J., 1927, 21, 823.

13. Peters, J. P., and Van Slyke, D. D., Quantitative Clinical Chemistry. Vol. I. Interpretations. Williams and Wilkins Co., Baltimore, 1931, p. 498.

14. Idem, page 927.

15. Peters, J. P., and Van Slyke, D. D., Quantitative Clinical Chemistry. Vol. II. Methods. Williams and Wilkins Co., Baltimore, 1932, p. 626.

16. Hartmann, A. F., and Senn, M. J. E., Studies in the metabolism of sodium $r$-lactate. III. Response of human subjects with liver damage, disturbed water and mineral balance, and renal insufficiency to the intravenous injection of sodium $r$-lactate. J. Clin. Invest., 1932, 11, 345. 